Print ISSN: 2233-4165 / Online ISSN: 2233-5382

doi:http://dx.doi.org/10.13106/ijidb.2019.vol10.no7.71

\title{
An Empirical Study of Comprehensive Health Screening Medical Service Quality with Kano Model and PCSI Index
}

\section{Kano 모델 및 PCSI 지수를 활용한 종합건강검진 의료서비스 품질에 대한 실증적 연구}

\author{
Ae-Jun PARK(박애준)*
}

Received: June 11, 2019. Revised: June 29, 2019. Accepted: July 05, 2019.

\section{Abstract}

Purpose - This study aims to identify the priorities of medical service quality improvement by customer satisfaction characteristics and potential customer satisfaction improvement (PCSI) index based on the dualistic quality classification of Kano Model (1984) for Comprehensive Health Screeening Center in General Hospitals and Centers only for Comprehensive Health Screening and suggest a direction for future improvement.

Research design, data, and methodology - Through advanced research on health screening medical service quality, this study set four service quality factors, including tangible, human, process and supportive factors, and 39 measurement items. Based on these items, the study used 117 questions, which consist of dualistic quality factors, customer satisfaction coefficients, positive and negative questions for PCSI index and questions for current satisfaction. 300 effective samples were collected for adults in their 20s who experienced health screening service in Seoul, Gyeonggi-do and Incheon within the past two years. Collected data were input in the quality evaluation duality table to categorize quality factors and calculate customer satisfaction coefficients by Timko(1993). The study also analyzed PCSI index in comparison with current satisfaction and identified priorities in quality improvement.

Results - It was found that the most urgent factors to improve the quality in both groups were adequate waiting hours and emergency response for complications, which are process factors classified as unitary quality. It is urgently needed to improve the quality as the PCSI index was high in supportive factors (complaint response team) as attractive quality in Comprehensive Health Screening Center in General Hospitals and in process factors (prevention of infection) as unitary quality in Centers only for Comprehensive Health Screening. As the PCSI index was low in space use as a tangible factor, it was found that the current level can be maintained instead of improvement.

Conclusions - To improve the health screening medical service quality, it is required to focus on process factors (adequate waiting hours, emergency response for complications, prevention of infection) and supportive factors (complaint response team) among service qualities perceived by users. It is proposed to ensure continuous efforts to manage and reinforce priorities as a direction for future improvement in health screening service.

Keywords: Comprehensive Health Screening, Kano Model, CS-Coefficient, PCSI Index.

JEL Classifications: I12, M11, M31.

\section{1. 서론}

우리나라 보건의료 환경에서 의료소비자 측면의 주요 변화

* Professor, Dept. of Healthcare Management, Catholic-Kwandong University, Korea. TEL: +82-33-649-7592, E-mail: ajcosmos62@cku.ac.kr

(i) Copyright: Korean Distribution Science Association (KODISA)
This is an Open Access article distributed under the terms of the Creative Commons Attribution Non-Commercial License (https:///creativecommons.org/licenses/by-nc/4.0/) which permits unrestricted non-commercial use, distribution, and reproduction in any medium, provided the original work is properly cited.
를 살펴보면, 인구의 고령화 현상 심화와 평균수명 증가, 만성 퇴행성질환으로의 질병구조 변화 그리고 국민소득 및 생활 수 준의 향상으로 건강한 삶을 추구하며 질병 예방과 건강증진에 대한 관심이 증가하고 있다. 질병 예방과 건강증진은 개인뿐만 아니라 국가와 사회차원에서도 관심이 높다. 우리나라의 건강 검진은 국가 일반검강검진(이하, 공공검진)과 민간 종합건강검 진(이하, 종합건강검진)으로 나뉜다. 종합건강검진 수가는 국민 건강보험공단의 정책적 통제 수가인 요양급여 기준을 적용받 지 않기 때문에 의료공급자 측면에서도 경영상 이윤확보 차원 
으로 매우 중요한 서비스라 할 수 있다(Kim, Lee, \& So, 2019). 또한 의료관광과 외국인환자 유치에 대한 관심이 높아 지면서 국내 외국인환자 유치의료기관들은 경쟁력이 높은 분 야 중 하나로 종합건강검진을 선택하여 적극적인 마케팅을 펼 친다. 이러한 의료 환경 변화는 건강검진에 대한 의료시장의 양적 팽창을 가져와 기관 간의 경쟁이 심화되어 가고 있다.

종합건강검진은 공공검진보다 이용자에 대한 사전, 사후 설 명이 자세하고, 질 높은 서비스를 제공하는 것으로 인식되고 있으며(Shin, Park, Jung, Jung, \& Kang, 2006), 만족도도 높 아서 고소득층을 중심으로 이용자가 확대된 것으로 파악되었 다(Kang, You, \& Kwon, 2009). 반면 Korea Consumer Agency (2017)에서 우리나라 Big5 병원(서울아산병원, 연세대 세브란스병원, 삼성서울병원, 서울대병원, 가톨릭대 서울성모 병원)의 종합건강검진 소비자만족도를 조사한 결과 5점 만점 에 3.73점으로 높지 않게 나와 세부적 조사 결과를 공유하며 취약한 부분에 대한 개선 노력을 기대하고 있다. 또한 종합건 강검진 검사항목이 필요 이상으로 많고, 선별검사로서 근거가 불충분한 검사들이 포함되어 있고, 비용-효과적이지 않으며, 병원의 수익 목적에 치우쳐 있다는 비판의 목소리도 있다 (Yang, Kim, Lee, \& Lee, 2006).

종합건강검진 의료서비스 시장이 안정적으로 성장하기 위해 서는 외형적인 확장에만 집중되지 않고 종합건강검진 의료서 비스 품질에 대한 실증적 연구를 바탕으로 지속적인 개선이 필요하다고 할 수 있다. 그러나 종합건강검진에 대한 의료서비 스 품질에 대한 연구와 개선 방향을 제시하는 연구가 미흡한 실정이다.

종합건강검진에 관한 연구는 개별 병원 이용자의 특성 분석 이나(Kim, Park, \& Kim, 2013), 선택요인 분석(Yeo \& Jeong, 2012; Park, Kim, \& Kang, 2015) 및 소규모 대상자들의 만족 도 분석(Im \& Choi, 2014)에 그치고 있다. 이에 따라 종합건강 검진 의료서비스 품질에 대한 구성 요인과 그에 따른 서비스 품질 분류 그리고 고객행동의도의 선행요인인 고객만족에 대 해 보다 면밀히 살펴볼 필요가 있다. 고객이 지각하는 주요 서 비스 품질이라 하더라도 이에 대한 물리적 요건과 감정적 요 건에 따라 만족도나 불만족도에서 지각 수준이 다르게 나타날 수 있다(Kano, Seraku, Takahashi, \& Tsuji, 1984). Kano 모델 은 서비스 품질을 2원적으로 분석함으로써 단순한 특정 서비 스 품질의 중요성뿐만 아니라, 소비자에게 인식되는 수준까지 파악하여 제시할 수 있다(Kim, Youn, \& Lee, 2018). 이에 본 연구에서는 종합건강검진 의료서비스 품질에 대한 지각을 주 관적인 만족감과 불만족감의 개념을 객관적인 서비스의 충족 과 불충족 요건에 따라 이원적으로 분석하여, 적극적 관리가 요구되는 품질 요소와 기본적 수준에서의 대응이 요구되는 품 질 요소 등에 대해 면밀히 파악하고자 한다. 또한 종합병원 내 건강검진센터와 종합건강검진 전문기관에서의 종합건강검진 의료서비스 품질 간에 차이가 있을 것으로 보고 구분하여 조 사하고자 하였다.

이를 통해 종합건강검진 서비스 품질의 지각 수준과 개선 우선순위를 제시함으로써 종합건강검진 수행 기관들의 경쟁력 제고와 서비스 개선을 위한 의사결정을 도와주고, 종합건강검 진 의료서비스 품질 개선의 효과를 높일 수 있는 실무적인 접 근방안을 제공하고자 한다.

\section{2. 선행연구 고찰}

\section{1. 종합건강검진}

건강검진은 질병의 조기 진단과 조기 치료를 통해 사망률 감소, 의료비 절감 등의 효과를 가져다준다(Maciosek, Coffield, Edwards, Flottemesch, Goodman, \& Solberg, 2006). 이용자 측에서 전액 부담하는 종합건강검진은 표준화된 공공검진보다 검사 항목이 훨씬 많고, 연령과 성별에 따른 위험요인과 개인 의 선호에 따라 검사항목을 달리하는 다양한 종류의 패키지가 있으며 가격도 다양하다(Kang et al., 2009). 종합건강검진은 주로 의료기관을 통해 이루어지고 있으며 공공검진보다 확대 된 개념의 건강검진이 종합건강검진이라고 할 수 있다(Kim et al., 2019). 종합건강검진 시설은 도입 초기인 1981년 2곳이던 것이 근래에는 대부분의 종합병원 내에서 종합건강증진센터로 독자적인 영역으로 자리를 잡아가고 있을 뿐만 아니라 별도의 건강검진센터(건강증진센터, 평생건강센터, 건강의학센터 등의 다양한 명칭 사용)를 설립하여 운영하는 경우도 늘고 있으며 서비스의 고급화와 경쟁도 심화되어 가고 있다(Kang et al., 2009).

\subsection{1. 의료서비스 품질 요인}

서비스품질이란 고객들이 이용한 기업으로부터 어떤 서비스 를 받았는가에 대한 기대와 경험을 통해 인지된 서비스이다 (Park \& Park, 2017). 최근 10년간 국내 연구를 보면, 일부 연 구자들은 서비스품질을 지각된 서비스품질 또는 전반적 품질 을 연구하는 Parasuraman, Zeithaml, and Berry (1985)와 SERVQUAL을 통해, 단일차원으로 접근하고 있으며, 다른 한 편으로는 다차원적인 접근으로 결과품질과 과정품질의 2차원 모형과, 상호작용, 결과, 물리적 환경 서비스 품질의 3 차원 관 점의 측정모형을 사용하고 있다(Lee, 2016). 의료서비스를 진 단과 치유에 대한 협의의 개념과 예방과 건강증진, 그리고 기 업이미지를 포함한 광의의 개념으로 보고 의료기관의 이미지 는 의료서비스 품질과 관계가 있고 의료서비스 품질은 의료서 비스 결과에 대해 영향을 준다(Choi \& Cho, 2015). 또한 의료 서비스 품질 중 인적품질과 서비스 전달과정 품질은 고객만족 과 행동의도에 유의한 영향을 준다(Lee \& Lee, 2014).

\subsection{2. 종합건강검진 의료서비스 품질 요인}

Yeo and Jeong(2012)은 공공검진과 종합건강검진 이용 결 정요인 분석을 통해 사회경제적 위치가 특히 종합건강검진의 수검에 중요한 영향을 미쳤으며, 종합건강검진이 건강생활 실 천에 긍정적인 효과가 있음을 파악하였다. 종합건강검진 서비 스 품질을 상호작용과 결과, 물리적 환경 품질로 구분하여 Kano 모델 분석과 서비스 가치, 고객만족, 행동의도에 미치는 영향 관계를 설명하였다(Lee, 2016). 종합건강검진 서비스의 외적서비스를 이용편의성으로 보고 절차 편의성과 시설 편의 성은 의료서비스 가치에 영향을 미치고 결정 편의성과 시설 편의성은 의료서비스 만족에 영향을 준다(Kim et al., 2019). 의료서비스 품질을 어떻게 개념화하는지의 여부는 연구자의 관점에 따라 상이하게 정의되어 왔다(Chung, 2016). Kano 모 델을 활용한 연구의 자료수집 방법은 설문조사를 통해 각 서 비스 품질 요인의 특성을 알아보는 것이다(Kim, Youn \& Lee, 
2018). 이에 기반을 두어 의료서비스 품질 요인을 기초로 하 고 종합건강검진 절차상에서 나타난 건강검진 과정의 특성에 초점을 맞추어 종합건강검진 의료서비스 품질 요인을 물리적 요인, 인적 요인, 과정적 요인, 지원 요인으로 재규정하여 Kano 모델에 적용하였다(Chung, 2016). SERVQUAL과 Kano 모델을 동시에 비교한 실증연구들도 보고되고 있다(Rahmana, Kamil, Soemantri, \& Olim, 2014; Basfirinci \& Mitra, 2015).

\subsection{Kano 모델}

일본 노리아키 카노가 제안한 Kano 모델(1984)은 제품개발 품질과 서비스 품질에 관련된 기획이론으로 고객만족도 측정 모델로 사용된다. 그는 기존의 일원적 품질 인식 방법을 대체 할 이원적 품질 인식 방법의 필요성을 확인하고, 만족과 불만 족이라는 주관적 측면, 물리적 충족과 불충족의 객관적 측면을 고려하여 Kano 모델을 만들었다(Kano et al., 1984). Kano 모 델에 의하면 품질에 대한 분류를 매력적 품질, 일원적 품질, 당연적 품질, 무관심 품질, 역 품질, 회의적 품질(응답의 모순) 등 6 가지로 <Table $1>$ 과 같이 구분된다. 이를 분류하기 위해 설문조사를 실시하는데, 측정 문항들은 긍정적·부정적 질문이 쌍을 이루고 이들의 응답 조합 분류에 따라 품질분류를 결정 하게 된다<Table 2>.

하지만 Kano 모델은 몇 가지 한계점을 가지고 있는데, 첫
째 품질 분류에서 가장 많은 응답수를 값으로 품질 특성을 결 정하므로 나타날 수 있는 값이 높거나 낮은 차이를 세부적으 로 반영할 수 없다(Kim, 2010; Salehzadeh, Shahin, \& Kazemi, 2015; Lee, Seo, \& Song, 2017; Kim, Youn, \& Lee, 2018). 또한 결정된 품질 요소를 고객이 어떻게 어느 정도로 받아들이는지 파악할 수 없어 고객만족 개선을 위한 방안 마 련에 한계가 있다(Timko, 1993). 그럼에도 불구하고 Kano모델 은 기존 일원적 품질 인식과 달리 제품이나 서비스 품질에 대 해 고객만족 특성을 파악할 수 있는 이원적 측정방법을 제시 하였다는 것에 의미를 찾을 수 있다.

\section{3. 고객만족계수(CSC) 및 잠재적 고객만족 개선 지 수(PCSI Index)}

Timko (1993)는 Kano 모델의 한계점을 보완하기 위하여 Kano 모델에서 품질 특성으로 분류된 결정계수로 고객만족계 수(CSC: Customer Satisfaction Coefficient)를 제안하였다 (Gruber, Abosag, Reppel, \& Szmigin, 2011; Dominici \& Palumbo, 2015). 고객만족계수는 품질특성에 대해 상대적으로 강하거나 약한 특성을 설명할 수 있다. 또한 장점으로 고객만 족 범위를 파악하여 향후 고객의 만족수준을 확인할 수 있다. 고객만족계수는 만족지수(SI: Satisfaction Index, Better)와 불 만족지수(DI: Dissatisfaction Index, Worse)로 나누고 만족지수 와 불만족지수의 산출법과 개념은 <Table 3>과 같다.

Table 1: Quality factors of Kano Model

\begin{tabular}{|c|c|}
\hline Quality factor & Characteristics \\
\hline Attractive Quality & $\begin{array}{l}\text { It causes satisfaction when answered by answering "like" to a positive question, but for negative questions it is } \\
\text { "must-be", "natural", "live with" Such a response is not dissatisfied with the response is not enough. }\end{array}$ \\
\hline $\begin{array}{l}\text { One-Dimensional } \\
\text { Quality }\end{array}$ & $\begin{array}{l}\text { If you are satisfied by answering a positive question by answering "like", you will be satisfied, and by answering } \\
\text { "dislike" to a negative question, you will also raise a complaint in case of insufficiency. }\end{array}$ \\
\hline Must-Be Quality & $\begin{array}{l}\text { There are no special responses to responses that are not displayed in response to a positive question, but } \\
\text { making a complaint in case of insufficiency by answering "dislike" to a negative question. }\end{array}$ \\
\hline Indifferent Quality & $\begin{array}{l}\text { In response to both positive and negative questions, no response will occur regardless of whether it is filled with } \\
\text { an undisplayed response. }\end{array}$ \\
\hline Reverse Quality & This can cause dissatisfaction if satisfied, and satisfaction if unsatisfactory. \\
\hline $\begin{array}{l}\text { Questionable } \\
\text { result }\end{array}$ & $\begin{array}{l}\text { It is very likely that the respondents did not respond correctly because they both responded positively or } \\
\text { negatively to both positive and negative questions. }\end{array}$ \\
\hline
\end{tabular}

Table 2: Kano evaluation table

\begin{tabular}{|c|c|c|c|c|c|c|}
\hline \multicolumn{2}{c|}{} & \multicolumn{4}{c|}{ Answers negative questions } \\
\cline { 2 - 7 } & like & like & must be & neutral & live with & dislike \\
\hline \multirow{3}{*}{$\begin{array}{c}\text { Answering positive } \\
\text { questions }\end{array}$} & must be & $\mathrm{Q}$ & $\mathrm{A}$ & $\mathrm{A}$ & $\mathrm{A}$ & $\mathrm{I}$ \\
\cline { 2 - 7 } & neutral & $\mathrm{R}$ & $\mathrm{I}$ & $\mathrm{I}$ & $\mathrm{I}$ & $\mathrm{M}$ \\
\cline { 2 - 7 } & live with & $\mathrm{R}$ & $\mathrm{I}$ & $\mathrm{I}$ & $\mathrm{I}$ & $\mathrm{M}$ \\
\cline { 2 - 7 } & dislike & $\mathrm{R}$ & $\mathrm{R}$ & $\mathrm{R}$ & $\mathrm{R}$ \\
\hline
\end{tabular}

A : Attractive

O : One-dimensional

M : Must-be

I : Indifferent

$\mathrm{Q}$ : Questionable result

R : Reverse 
Table 3: Timko's Concept and Methods for CSC calculation

\begin{tabular}{|c|c|c|}
\hline Classification & Improved satisfaction with expectations(Better) & Decreased expectations dissatisfaction(Worse) \\
\hline \multirow[b]{2}{*}{ Formula } & $(\mathrm{A}+\mathrm{O}) /(\mathrm{A}+\mathrm{O}+\mathrm{M}+\mathrm{I})$ & $\{(\mathrm{O}+\mathrm{M}) /(\mathrm{A}+\mathrm{O}+\mathrm{M}+\mathrm{I})\}(-1)$ \\
\hline & $\begin{array}{l}\text { A : Attractive } \\
M: \text { Must-be }\end{array}$ & $\begin{array}{l}\mathrm{O}: \text { One-dimensional } \\
\mathrm{I}: \text { Indifferent }\end{array}$ \\
\hline Concept & $\begin{array}{l}\text { Expectations to improve customer satisfaction when } \\
\text { meeting customer needs }\end{array}$ & $\begin{array}{l}\text { Expectations to reduce customer complaints when } \\
\text { meeting customer needs }\end{array}$ \\
\hline
\end{tabular}

Source : Walden, D.(1993). Introduction to kano's methods. In D. Walden (Ed), Kano's methods for understanding customer-defined quality, p.8 The center for Quality of management, Inc.

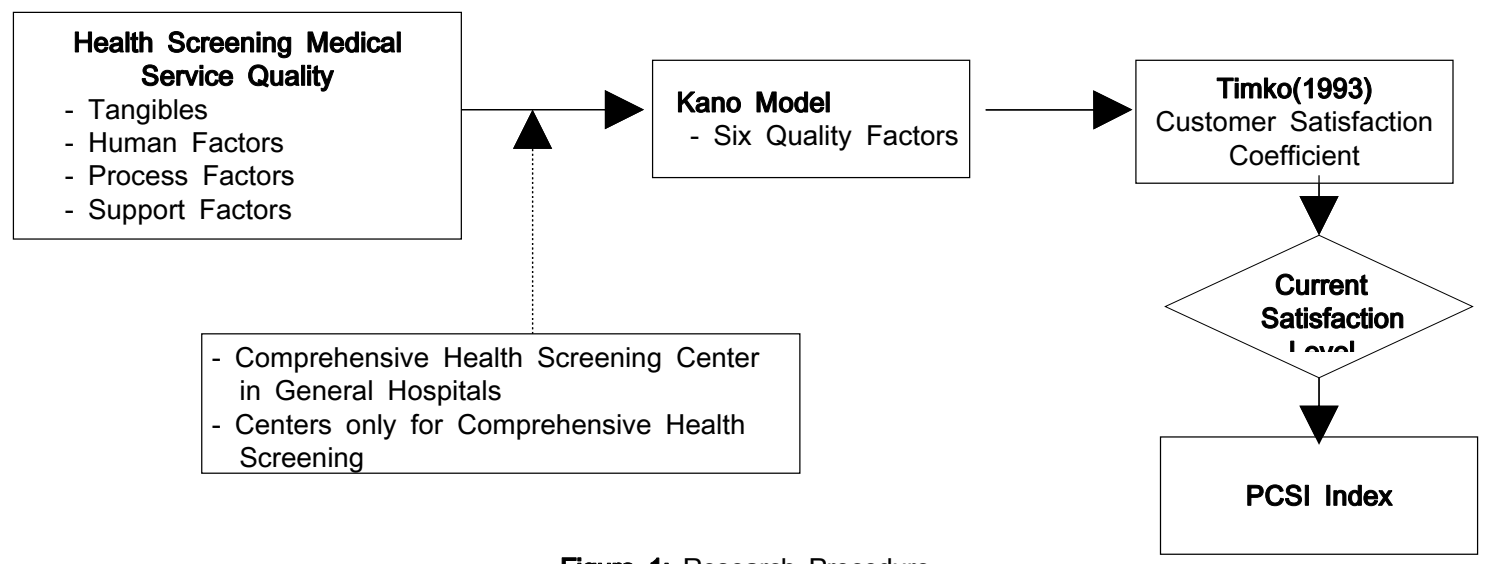

Figure 1: Research Procedure

잠재적 고객만족 개선 지수(PCSI Index: Potential Customer Satisfaction Improvement Index)는 제품이나 서비스에 대한 고 객의 요구 사항이 일정 부분 충족되었을 경우 현재의 고객만 족도를 추출해 냄으로써 만족도가 전에 비하여 얼마나 더 개 선될 수 있는지를 파악하는 방법이다(Lim \& Park, 2010; Taifa \& Desai, 2015; Shahin, 2016). 잠재적 고객만족 개선 지수 (PCSI Index) 산출법은 다음과 같다.

$$
\begin{aligned}
& \mathrm{P}=\{(\mathrm{S}-\mathrm{D}) \times(\operatorname{Max}-\mathrm{L}) / \mathrm{Max}-\mathrm{Min}\}+\mathrm{D} \text { PCSI 지수 = S-P } \\
& \mathrm{P}: \text { 현재의 만족 위치. S : 만족지수. } \\
& \mathrm{D}: \text { 불만족지수. L : 현재의 만족수준 (Current Level). } \\
& \text { Max : 현재 만족수준 척도 중 최대값. } \\
& \text { Min : 현재 만족수준 척도 중 최소값. }
\end{aligned}
$$

잠재적 고객만족 개선 지수는 만족지수까지의 거리를 현재 의 만족 위치로부터 측정하여 나타낸 값이다. 현재의 만족 위 치는 서비스 품질 속성에 대하여 고객의 현재의 만족수준을 확인한 후, 고객만족계수의 만족지수와 불만족지수 사이에 현 재의 만족수준을 위치시켜 고객의 현재의 만족 위치를 파악하 는 것이다.

\section{3. 연구방법}

\section{1. 연구방법 및 절차}

본 연구는 의료서비스 품질 관련 선행연구(Cronin \& Taylor,
1992; Brady \& Cronin, 2001; Milutinović, Milovanović, Pjević, Martinov-Cvejin, \& Cigić, 2009; Kim \& Park, 2015)를 검토한 후, 선행 연구에 기반을 두어 Jung(2016)이 종합건강검진 의 료서비스 품질 측정을 위해 개발한 타당성과 신뢰도가 검증된 측정도구를 개발자의 동의하에 사용하였다. 종합건강검진 의료 서비스 품질에 대해 4가지(물리적, 인적, 과정적, 지원) 품질 요인으로 구분하여 39 개 측정문항을 설정하였다. 분석은 Kano 모델 분석, 고객만족계수(CSC), 잠재적 고객만족 개선 지수 (PCSI Index) 산출에 맞도록 긍정적 질문(39개 문항)과 부정적 질문(39개 문항), 만족도 질문(39개 문항)으로 재구성한 총 117 개 문항을 사용하였다. 이를 통해 종합병원 내 건강검진센 터를 이용한 수진자 집단에서 얻은 자료와 종합건강검진 전문 기관을 이용한 수진자 집단에서 얻은 자료에 대해 각각 Kano 모델 분석 평가 이원표에 대입하여 서비스 품질 특성 분류와 Timko(1993)의 고객만족계수를 산출하였다. 또한 39개의 측정 문항별 현재 만족수준과 잠재적 고객만족 개선 지수(PCSI Index)를 산출하여 종합건강검진 의료서비스 품질 측정 문항별 개선 우선순위를 파악하고 두 집단 간의 차이를 비교하였다. 연구절차는 <Figure 1 과 같다

\section{2. 자료수집방법}

본 연구는 기관생명윤리심의위원회의 승인(IRB No. CKU-19-01-0205)을 받아 진행하였으며, 자료는 2019년 5월 31 일부터 5일 동안 온라인 리서치 전문회사인 $\mathrm{M}$ 사의 패널을 이용하여 수집하였다. 연구 대상은 20세 이상 성인으로서 최 근 2 년 이내 서울, 경기, 인천 지역에서 종합병원 내 건강검진 
센터나 종합건강검진 전문기관에서 내시경 및 초음파 등을 포 함한 종합건강검진을 1 회 이상 받아본 경험이 있는 응답자들 을 대상으로 표본을 편의추출하여 종합병원 내 건강검진센터 이용 경험자 150 명과 종합건강검진 전문기관 이용 경험자 150 명에게 설문조사를 실시하여 유효표본 300부를 수집하였다.

\section{4. 연구결과}

\section{1. 표본의 일반적 특성}

표본의 일반적 특성은 종합병원 내 건강검진센터 이용자들 을 살펴보면, 성별은 남성 47 명(31.3\%), 여성 103명(68.7\%)으 로 여성이 많았으며, 연령대는 30 대가 65 명 $(43.3 \%)$ 으로 가장 많았고, 30대 미만 35명(23.3\%), 40대 26명(17.3\%), 50대 17 명(11.3\%), 60대 이상 7 명(4.7\%) 순으로 나타났다. 직업은 회 사원인 경우가 91 명 $(60.7 \%)$ 으로 가장 많았고, 전문직과 주부 가 각각 16 명 $(10.7 \%)$, 자영업 8 명(5.3\%) 등의 순으로 나타났 다. 거주 지역은 서울거주가 82 명 $(54.7 \%)$ 으로 가장 많았고, 경 기 53명(35.3\%), 인천 15명(10.0\%) 순으로 나타났다.

종합건강검진 전문기관 이용자들을 살펴보면, 성별은 남성 67 명(44.7\%), 여성 83명(55.3\%)으로 여성이 좀 더 많았으며, 연령대는 30 대가 59 명(39.3\%)으로 가장 많았고, 40 대 50 명 $(33.3 \%), 50$ 대 21 명 $(14.0 \%), 30$ 대 미만 14 명 $(9.3 \%), 60$ 대 이 상 6 명 $(4.0 \%)$ 순으로 나타났다. 직업은 회사원인 경우가 108 명(72.0\%)으로 가장 많았고, 주부 17 명 $(11.3 \%)$, 전문직 7 명 $(4.7 \%)$ 등의 순으로 나타났다. 거주 지역은 서울거주가 81 명
$(54.0 \%)$ 으로 가장 많았고, 경기 51 명(34.0\%), 인천 18 명 $(12.0 \%)$ 순으로 나타났다.

\section{2. 종합건강검진 의료서비스 품질에 대한 Kano 모델 분석 결과}

\subsection{1 종합병원 내 건강검진센터 이용자}

종합병원 내 건강검진센터 이용자의 Kano 모델 분석결과 (<Table 4> 참조)를 살펴보면, 매력적 품질은 전체 품질 중 $38.5 \%$ 인 15 개이며, 대기공간 편의시설, 분실방지용 수납용기, 대기실 충전기, 검사 진행파악 개인장비, 접수/대기순번 안내, 결과지 내용 중요도표시, 검사 안내 영상, 유명 의료진, 검사 결과 즉시 설명, 초음파 시 따뜻한 젤 사용, 빠른 결과확인, 주차대행 서비스, 정체 시 대기열 재배치, 검사 후 식사 제공, 맞춤 후속관리 등으로 파악되었다. 일원적 품질은 전체항목의 $56.4 \%$ 를 차지하고 있으며, 검사실간 동선, 2차회복공간, 탈착 용이한 수진자 가운, 내시경 기구 소독 공개, 공간/의복 청결 상태, 대기순서 파악, 내시경 동의서 가독성, 예약 시 충분한 설명, 의료진 친절수준, 검사 전 안내, 검사 중 상세안내, 예약 편의, 과거병력 재확인, 의심 증상 추가검사, 합병증 응급대응, 여성산부인과의사, 내시경 후 휴식, 감염예방 위생관리, 적절 한 대기시간, 진료과 연계, 과거검진이력 $\mathrm{DB}$, 불만 해소 전문팀 등 과반수가 일원적 품질인 것으로 나타났다. 이외에도 무관심 품질은 남녀 검진 구역 분리와 직급 표시 명찰 등으로 확인되 었다.

Table 4: Kano Model Analysis Results

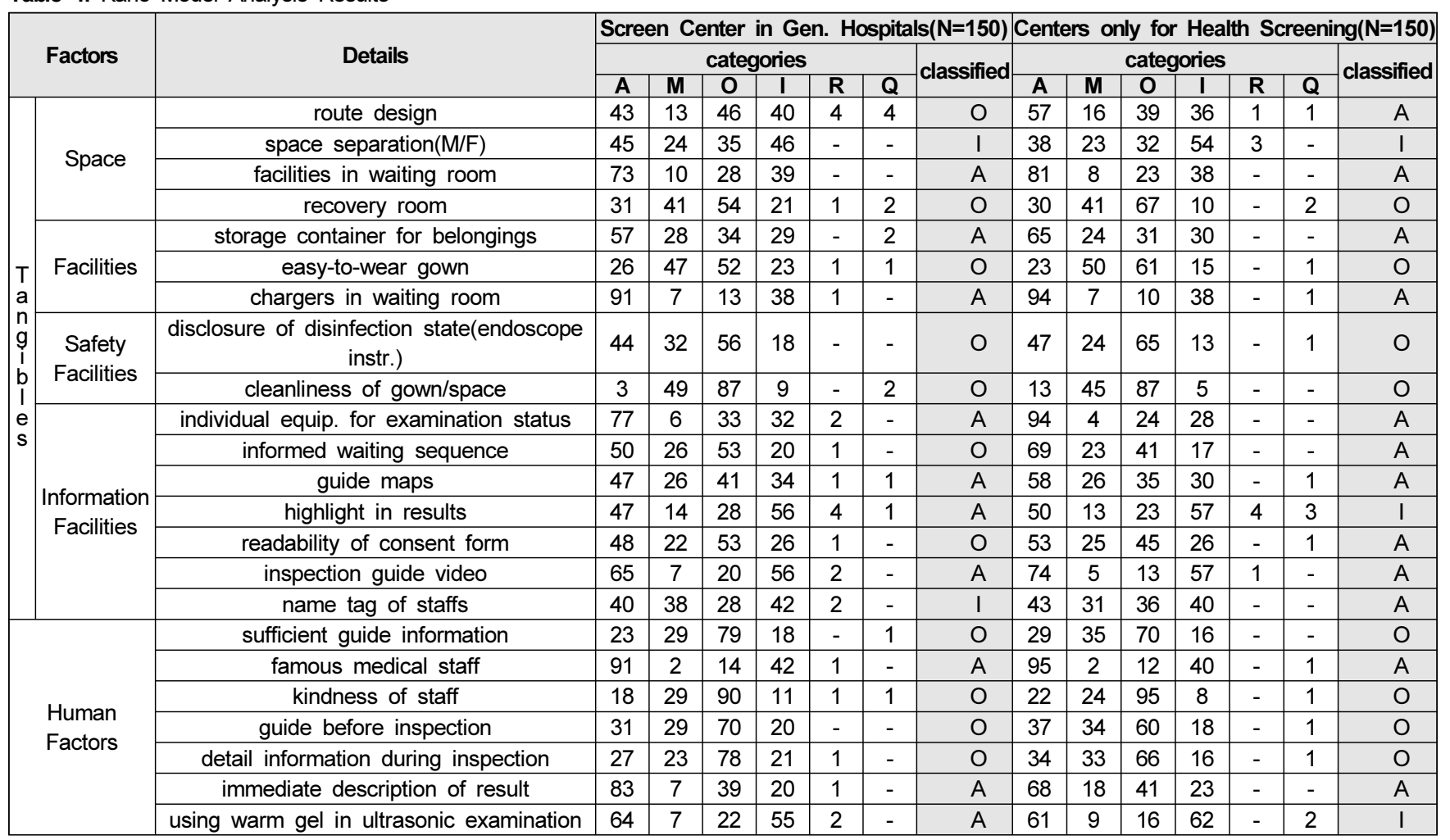




\begin{tabular}{|c|c|c|c|c|c|c|c|c|c|c|c|c|c|c|c|}
\hline \multirow{10}{*}{$\begin{array}{l}\text { Process } \\
\text { Factors }\end{array}$} & convenient booking & 28 & 21 & 83 & 18 & - & - & $\mathrm{O}$ & 32 & 35 & 71 & 11 & - & 1 & $\mathrm{O}$ \\
\hline & past history re-check & 15 & 42 & 60 & 32 & 1 & - & $\mathrm{O}$ & 29 & 53 & 44 & 23 & - & 1 & $\mathrm{M}$ \\
\hline & $\begin{array}{c}\text { additional inspection for suspicious } \\
\text { symptom }\end{array}$ & 33 & 34 & 69 & 14 & - & - & $\mathrm{O}$ & 49 & 15 & 63 & 22 & - & 1 & $\mathrm{O}$ \\
\hline & emergency response for complications & 12 & 42 & 81 & 14 & - & 1 & $\mathrm{O}$ & 24 & 37 & 78 & 10 & - & 1 & $\mathrm{O}$ \\
\hline & $\begin{array}{l}\text { Female Gynecologist } \\
\text { (for women only) }\end{array}$ & 41 & 6 & 45 & 11 & - & - & $\mathrm{O}$ & 37 & 7 & 31 & 8 & - & - & A \\
\hline & rest after endoscopy & 19 & 27 & 91 & 13 & - & - & $\mathrm{O}$ & 20 & 33 & 86 & 10 & - & 1 & $\mathrm{O}$ \\
\hline & prevention of infection & 4 & 61 & 74 & 11 & - & - & $\mathrm{O}$ & 7 & 53 & 80 & 9 & - & 1 & $\mathrm{O}$ \\
\hline & not too long waiting time & 37 & 10 & 85 & 18 & - & - & $\mathrm{O}$ & 48 & 14 & 67 & 20 & - & 1 & 0 \\
\hline & quick results notification & 74 & 9 & 47 & 19 & - & 1 & A & 78 & 9 & 44 & 18 & - & 1 & A \\
\hline & clinical connection & 39 & 23 & 73 & 15 & - & - & $\mathrm{O}$ & 55 & 16 & 59 & 19 & - & 1 & $\mathrm{O}$ \\
\hline \multirow{6}{*}{$\begin{array}{l}\text { Support } \\
\text { Factors }\end{array}$} & DB of past checkups & 55 & 17 & 60 & 18 & - & - & $\mathrm{O}$ & 62 & 10 & 53 & 24 & 1 & - & A \\
\hline & valet service & 74 & 2 & 13 & 61 & - & - & $A$ & 79 & 3 & 10 & 57 & 1 & - & A \\
\hline & queue relocation & 67 & 6 & 55 & 22 & - & - & A & 84 & 7 & 39 & 20 & - & - & A \\
\hline & meals served & 98 & 3 & 21 & 28 & - & - & A & 101 & 5 & 17 & 27 & - & - & A \\
\hline & customized follow-up & 87 & 2 & 26 & 35 & - & - & $A$ & 89 & 1 & 14 & 46 & - & - & A \\
\hline & complaint response team & 50 & 11 & 68 & 21 & - & - & 0 & 68 & 7 & 50 & 25 & - & - & A \\
\hline \multicolumn{2}{|r|}{ Classification } & \multicolumn{7}{|c|}{$O(22) A(15) I(2)$} & \multicolumn{3}{|c|}{$A(20)$} & O(15) & $I(3)$ & \multicolumn{2}{|c|}{ M(1) } \\
\hline
\end{tabular}

\subsection{2 종합건강검진 전문기관 이용자}

종합건강검진 전문기관 이용자의 Kano 모델 분석결과 (<Table 4>참조)를 살펴보면, 매력적 품질은 전체의 $51.3 \%$ 를 차지하고 있으며, 검사실간 동선, 대기공간 편의시설, 분실방 지용 수납용기, 대기실 충전기, 검사 진행파악 개인장비, 대기 순서 파악, 접수/대기순번 안내, 내시경 동의서 가독성, 검사 안내 영상, 직급 표시 명찰, 유명 의료진, 검사결과 즉시 설명, 여성산부인과의사, 빠른 결과확인, 과거검진이력 $\mathrm{DB}$, 주차대행 서비스, 정체 시 대기열 재배치, 검사 후 식사 제공, 맞춤 후 속관리, 불만 해소 전문팀 등 20개로 파악되었다. 일원적 품질 은 15 개로 $38.5 \%$ 를 차지하며, 2 차 회복공간, 탈착 용이한 수 진자 가운, 내시경기구 소독공개, 공간/의복 청결, 예약 시 충 분한 설명, 의료진 친절, 검사 전 안내, 검사 중 상세안내, 예 약편의, 의심 증상 추가검사, 합병증 응급대응, 내시경 후 휴 식, 감염예방 위생관리, 적절한 대기시간, 진료과 연계인 것으 로 확인되었다. 이외에도 무관심 품질은 남녀 검진 구역 분리, 결과지 내용 중요도표시, 초음파 시 따뜻한 젤 사용 등이며, 당연적 품질은 과거병력 재확인으로 나타났다.

\section{3. 종합건강검진 의료서비스 품질에 대한 고객만족 계수 분석결과}

Kano 모델 분석결과를 바탕으로 Timko(1993)의 고객만족계 수를 산출하였다<Table 5>. 이를 통해, Kano 분석과 달리 만 족과 불만족의 영향 정도를 파악할 수 있으며, 차이가 나는 품 질을 중심으로 파악하면 <Table $5>$ 와 같다.

종합병원 내 건강검진센터 이용자의 경우, Timko(1993)의 고객만족계수 분석결과를 살펴보면, '검사실간 동선'과 '여성산
부인과의사'가 Kano 모델에서의 일원적 품질에서 매력적 품질 로 분류되었다. 또한 '남녀 검진 구역 분리'는 무관심 품질에서 매력적 품질로 변화하였다.

종합건강검진 전문기관 이용자의 경우, Kano 모델에서는 무관심 품질인 '결과지 내용 중요도 표시'와 '초음파 시 따뜻한 젤 사용'이 고객만족계수 분석에서는 매력적 품질로 파악되었 다.

고객만족계수에서 고객의 니즈충족 $\rightarrow$ 고객만족향상으로 귀결 되는 기대수준정도를 파악한 만족계수가 높은 항목으로는 종 합병원 내 건강검진센터 이용자의 경우, 여성산부인과의사 $(0.83)$, 검사결과 즉시설명 $(0.82)$, 적절한 대기시간 $(0.81)$, 빠른 결과확인 $(0.81)$, 정체 시 대기열 재배치(0.81), 검사 후 식사 제공 $(0.79)$, 불만 해소 전문팀( 0.79$)$, 과거검진이력 $\mathrm{DB}(0.77)$, 진 료과 연계(0.75), 맞춤후속관리(0.75)인 것으로 파악되었다. 종 합건강검진 전문기관 이용자의 경우, 정체 시 대기열 재배치 $(0.82)$, 빠른 결과확인( 0.82$)$, 여성산부인과의사( 0.82$)$, 검사 진 행파악 개인장비(0.79), 의료진 친절(0.79), 검사 후 식사 제공 $(0.79)$, 불만 해소 전문팀 $(0.79)$, 적절한 대기시간(0.77), 진료과 연계(0.77), 과거검진이력 $\mathrm{DB}(0.77)$, 내시경기구 소독공개(0.75), 의심 증상 추가검사(0.75) 등으로 확인되었다.

고객만족계수에서 불만족계수가 높은 항목 즉, 고객의 니즈 를 충족시키면 불만이 감소되는 것으로 파악되는 항목으로는 종합병원 내 건강검진센터 이용자의 경우, 공간/의복 청결 $(-0.92)$, 감염예방 위생관리(-0.90), 합병증 대응(-0.83), 의료진 친절(-0.80), 내시경 후 휴식(-0.79) 등이며, 종합건강검진 전문 기관 이용자의 경우, 감염예방 위생관리(-0.89), 공간/의복 청결 $(-0.88)$, 의료진 친절(- -0.80$)$, 내시경 후 휴식(- 0.80$)$, 합병증 대 응(-0.77) 등으로 나타났다. 
Table 5: Customer Satisfaction Coefficient of the quality of health screening medical service

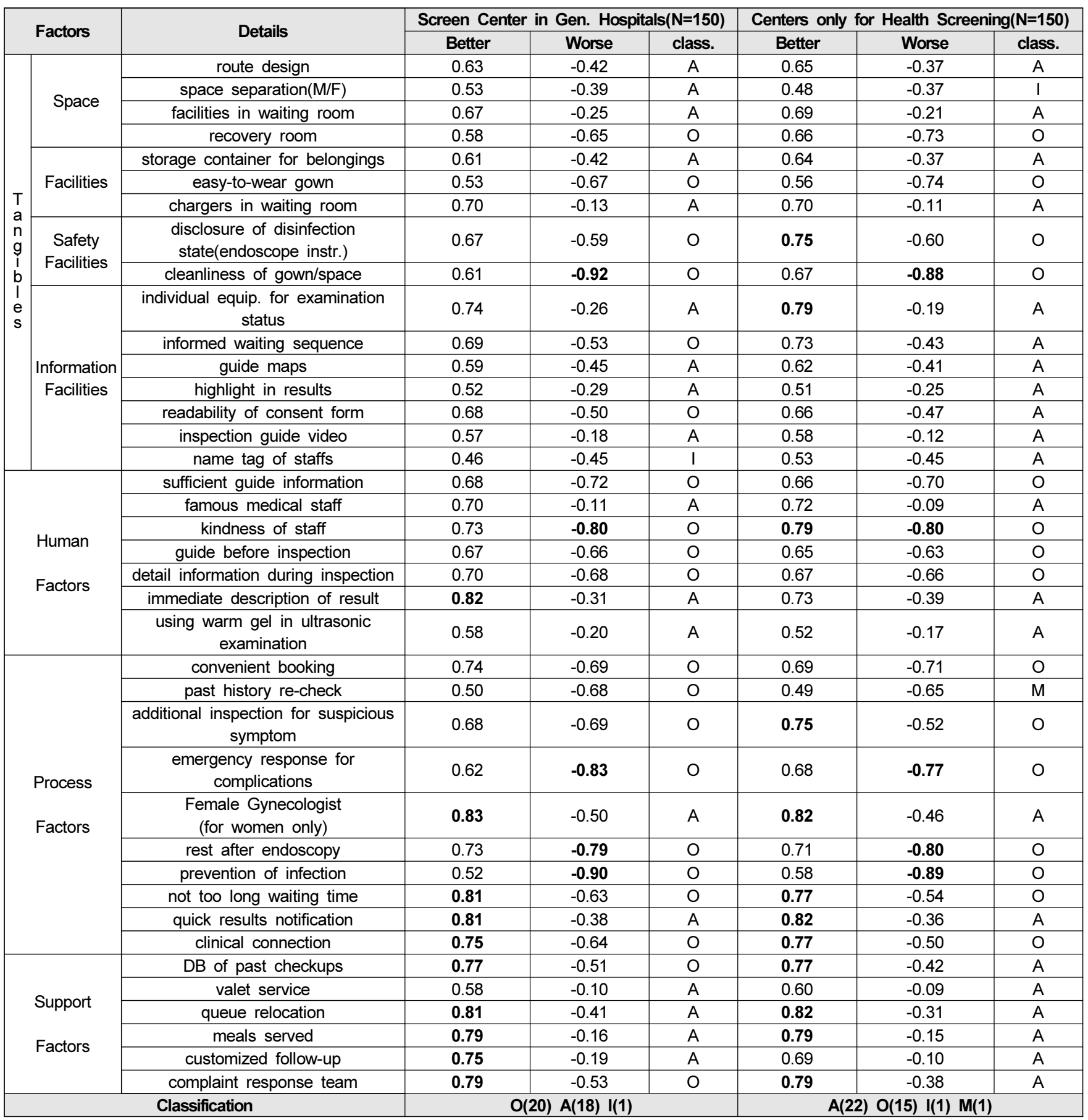

\section{4. 잠재적 고객만족 개선 지수(PCSI Index) 분석결과}

종합건강검진 의료서비스 품질 문항별로 현재 만족 위치를 기준으로 고객의 인식에서 개선여지를 파악하기 위해 PCSI 지수를 산출하고 개선우선 순위를 파악하였다<Table 6>.
종합병원 내 건강검진센터의 현재 만족위치는 여성산부인과 의사(0.49), 검사결과 즉시 설명 $(0.44)$, 검사 후 식사 제공 (0.38), 유명 의료진(0.35), 맞춤 후속관리(0.34) 순으로 높았으 며, 감염예방 위생관리(-0.03), 합병증 대응(0.04), 공간/의복 청 결 $(0.04)$, 탈착 용이한 수진자 가운(0.05), 과거병력 재확인 $(0.08)$ 등이 낮았다. 
Table 6: PCSI Index of the quality of health screening medical service

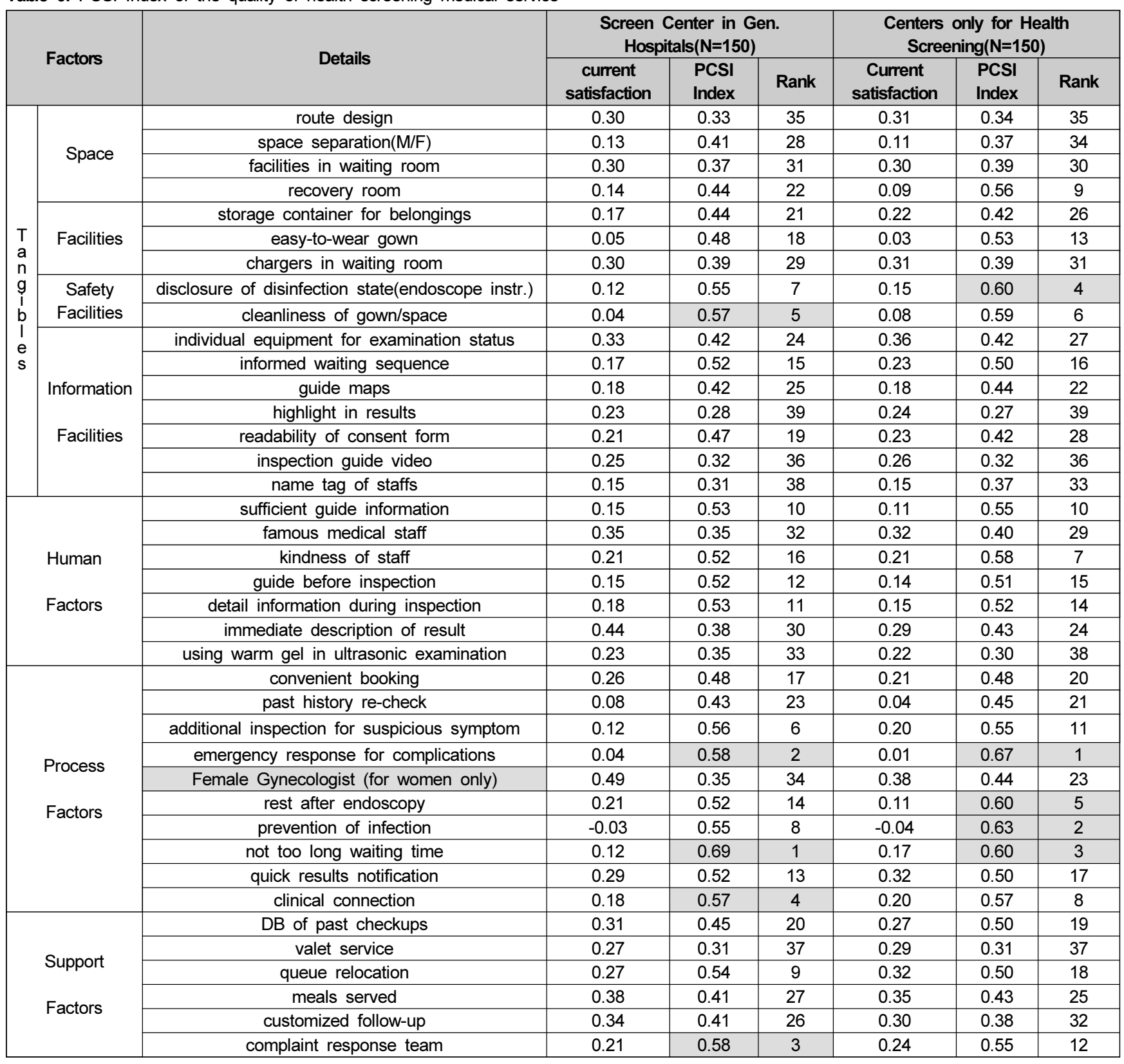

종합병원 내 건강검진센터의 PCSI 지수가 높은 항목을 살 펴보면, 적절한 대기시간(0.69), 합병증 대응(0.58), 불만 해소 전문팀(0.58), 진료과 연계(0.57), 공간/의복 청결(0.57) 등이 개 선의 여지가 많은 것으로 나타났다.

종합건강검진 전문기관의 현재 만족위치는 여성산부인과의 사(0.38), 검사 진행파악 개인장비(0.36), 검사 후 식사 제공 (0.35), 정체 시 대기열 조절(0.32), 유명 의료진(0.32) 순으로 높았으며, 감염예방 위생관리(-0.04), 합병증 대응(0.01), 탈착 용이한 수진자 가운(0.03), 과거력 확인(0.04), 공간/의복 청결 $(0.08)$ 등이 낮았다.
종합건강검진 전문기관의 PCSI 지수가 높은 항목을 살펴보 면, 합병증 대응(0.67), 감염예방 위생관리(0.63), 적절한 대기 시간(0.60), 내시경기구 소독공개(0.60), 내시경 후 휴식(0.60) 등이 개선의 여지가 많은 것으로 나타났다.

종합병원 내 건강검진센터와 종합건강검진 전문기관의 개선 PCSI지수의 최대값과 최소값을 기준으로 상대적 비교를 위해 임의의 3 개 구간으로 나누었는데, PCSI 지수가 0.55 이상의 개선이 시급한 영역, $0.40 ~ 0.55$ 사이의 개선고려영역, 0.25 0.40 사이의 현 상태 유지 영역으로 구분하여, 각 영역별로 포 함된 요인과 세부항목을 비교하였다. 
비교결과, $\mathrm{PCSI}$ 지수 0.55 이상의 개선시급구간의 경우, 종 합병원 내 건강검진센터에서는 전체 항목 39 개 중에 $20.5 \%$ 에 해당하는 8 개 항목이 해당되며, 세부적으로는 적절한 대기시 간(0.69), 합병증 대응(0.58), 불만 해소 전문팀(0.58), 진료과 연계(0.57), 공간/의복 청결(0.57), 의심 증상 추가검사(0.56), 내시경기구 소독공개(0.55), 감염예방 위생관리(0.55) 등이 해 당 구간으로 분류되었다. 종합건강검진 전문기관의 경우, 전체 항목 39 개 중에서 $30.7 \%$ 인 12 개 항목이 개선이 시급한 것으
로 분류되었으며, 세부적으로는 합병증 대응(0.67), 감염예방 위생관리(0.63), 적절한 대기시간(0.60), 내시경기구 소독공개 (0.60), 내시경 후 휴식(0.60), 공간/의복 청결(0.59), 의료진친 절(0.58), 진료과 연계(0.57) 2차 회복공간(0.56), 예약 시 충분 한 설명(0.55), 의심 증상 추가검사(0.55), 불만 해소 전문팀 (0.55) 등이 해당구간으로 분류되었다. PCSI 지수를 비교한 영 역별 각각 대표적인 3 가지 결과는 <Figure $2>$ 와 같다.

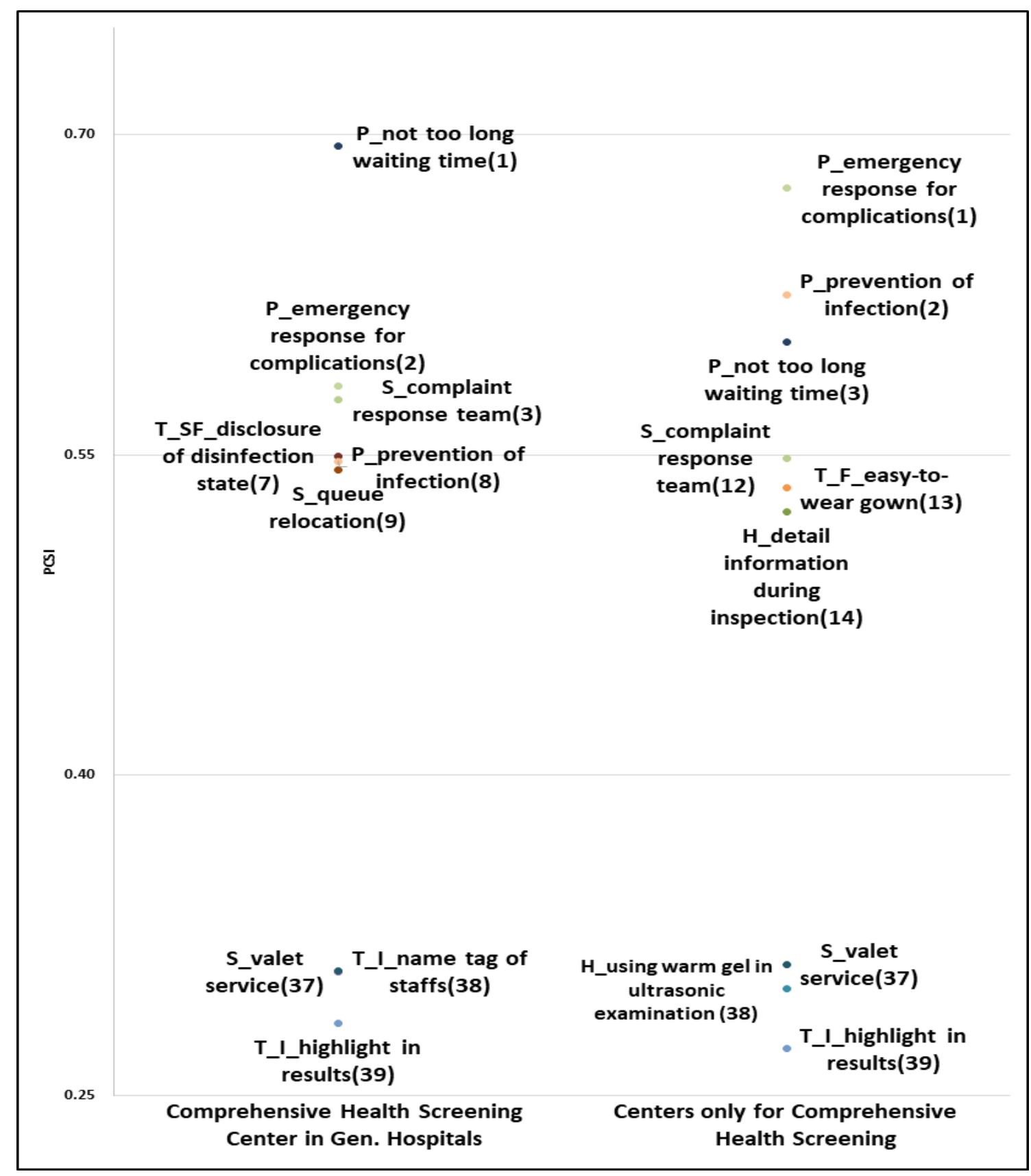

Figure 2: PCSI Index comparison between two groups 


\section{5. 결론}

\section{1. 결과요약 및 시사점}

본 연구에서는 종합병원 내 건강검진센터 이용자와 종합건강 검진 전문기관 이용자를 대상으로 종합건강검진 의료서비스 품 질을 물리적 요인, 인적 요인, 과정적 요인, 지원요인으로 구분 하고 세부 문항에 대하여 카노 모델을 적용하여 서비스 품질분 류와 고객만족 특성을 파악하였다. 또한 Timko(1993)의 고객만 족계수를 통해 만족 정도와 불만족 정도에 대한 강한 특성과 약 한 특성을 구분하고 잠재적 고객만족개선 지수를 통해 종합건강 검진 의료서비스 품질에 대한 개선 우선순위를 도출하였다.

연구 결과와 시사점을 살펴보면, 첫째 카노 모델을 통한 품 질 분류별 고객만족 특성은 종합병원 내 건강검진센터의 경우 일원적 품질이 22 개로 가장 많았고, 매력적 품질이 15 개, 무관 심 품질이 1 개로 나왔으며, 종합건강검진 전문기관의 경우 매력 적 품질이 20 개로 가장 많고 일원적 품질이 15 개, 무관심 품질 이 1 개, 당연적 품질이 1 개로 분류되어 두 집단 모두 매력적 품 질과 일원적 품질에 집중되는 비슷한 결과가 나왔다. 품질 분류 상 많은 비중을 차지하는 일원적 품질은, 충족여부에 따라 만족 과 불만을 나타내는 품질로 종합건강검진 수행 기관들에서는 현재의 만족 수준에 대해 주기적으로 측정해가며 부족한 부분 을 충족시키는 지속적인 관리가 필요한 부분이다. 매력적 품질 의 경우 서비스를 제공 받았을 때 만족도를 증대 시키며 제공 받지 못하더라도 불만을 유발하지 않는 특성을 보이는 품질로 고객감동의 원천이 된다. 따라서 종합건강검진 수행 기관들의 차별화 전략을 위해 집중하여 도입해 나아가는 것이 필요한 부 분이다. 특히, 서비스 품질 요인 중 기관의 자발성과 준비성을 의미하는 지원적 요인, 즉 주차대행 서비스, 정체 시 대기열 재 배치, 검사 후 식사 제공, 고객별 맞춤 후속관리 등이 대부분 매력적 품질로 분류되었다. 이러한 서비스 품질 분류별 고객만 족 특성을 이해하고 접근해 가는 것이 효과적이라 할 수 있다.

둘째, 산출된 고객만족계수를 기준으로 Kano 모델의 품질 분류를 다시 매력적, 일원적, 무관심, 당연적 품질의 4 사분면 으로 분류한 결과, Kano 모델 품질 분류와 유사하게 일원적 품질과 매력적 품질로 집중화되는 결과를 보였다. 고객만족 계 수를 통해 더욱 의미 있게 보아야 할 부분인 상위 5 개 문항에 대해서는 <Table $6>$ 와 같이 정리하였으며, 이들 문항에 대해 서는 충족 여부에 따라 만족도 증대와 불만족 개선에 영향이 크므로, 고객만족을 극대화하기 위해 기관에서는 최우선으로 고려되어야 하며, 도입하여 적용 시 담당 의료진 및 직원들에
게도 중요성 인식과 그에 따른 교육 훈련도 지속해 나아가야 할 부분이다.

셋째, 잠재적 고객만족 개선 지수를 통한 개선 우선순위 결 과는 개선을 필요로하는 양상이 요인별, 문항별로 다양하고 복 잡하게 나타났으며, 두 집단 간에도 차이를 보였다, 두 집단에 서 개선이 가장 시급한 최우선적인 3 개 문항에 대해 살펴보면, 종합병원 내 건강검진센터에서는 검사 대기시간 관리(0.69), 합병증(출혈, 천공, 쇼크 등) 발생 시 응급대처와 보호자 호출 등의 응급 대응 시스템 운영(0.58), 고객 불만 해소 전문팀 운 영(0.58)으로 나타났으며, 종합건강검진 전문기관에서는 합병 증(출혈, 천공, 쇼크 등) 발생 시 응급대처와 보호자 호출 등의 응급 대응 시스템 운영(0.67), 감염예방 위생관리(0.63), 검사 대기시간 관리(0.60)로 나타나, 합병증(출혈, 천공, 쇼크 등) 발 생 시에 대한 응급대처와 보호자 호출 등의 대응 시스템 운영 과 검사 대기시간 관리는 두 집단 모두 최우선으로 개선이 필 요하며 종합건강검진 전문기관의 경우, 감염관리 중요성에 대 한 고객 눈높이의 변화를 반영하여 감염예방 위생관리 상황을 고객들이 직접 가시적으로 확인할 수 있는 환경 마련과 시스 템적 정비가 필요하다. 또한 종합병원 내 건강검진센터의 고객 불만 해소 전문팀 운영에 대해서는 종합병원 내에 있는 전체 내원객을 대상으로 하는 고객 불만 해소 전담팀과는 별도로 종합건강검진 수진자를 위한 전담팀의 운영을 요구하고 있다 는 것을 알 수 있다. 이러한 문항들을 중심으로 개선이 시급한 구간에 속한 문항들에 대해 우선으로 개선해 나아가고 중위권 영역의 항목들은 향후 개선에 고려되어야 할 것이며, 물리적 요인인 공간사용 등 하위권 영역의 경우는 현재의 상태를 잘 유지해 나아가는 단계별 전략적 접근이 필요할 것으로 보인다.

본 연구는 종합건강검진에 관한 이용자 특성 분석이나, 종 합건강검진 선택요인 분석, 이용자들의 일원적 품질 만족도를 주로 분석한 선행연구들과는 다르게 서비스 품질 분석에 대해 Kano 모델을 적용하여 이원적 서비스 품질 분석을 시행하여 종합건강검진 이용자들의 니즈를 구체적으로 파악하였다. 이는 한정된 자원을 활용하여 어떠한 서비스가 고객에게 만족을 넘 어 고객감동을 줄 수 있는 서비스인지 그리고 어떠한 서비스 가 제공되지 않을 때 불만족을 증가시키는지 두 집단별로 파 악하여 경영전략 수립에 사용할 수 있다. 또한 종합건강검진 의료서비스 품질 분류별 고객만족 특성을 파악하고 기관 간 경쟁이 치열한 상황에서 종합건강검진 의료서비스 품질에 대 해 고객만족을 증대시킬 수 있는 차별적이고 구체적인 접근 방안과 개선 우선순위를 제시하였다는 점에서 실무적으로 기 여하는 바가 크다 할 수 있다.

Table 7: Top 5 items of Customer Satisfaction Coefficient

\begin{tabular}{|c|c|c|c|c|c|}
\hline \multirow{2}{*}{$\csc$} & \multirow{2}{*}{ RANK } & \multicolumn{2}{|c|}{ Screen Center in General Hospitals ( $N=150)$} & \multicolumn{2}{|l|}{ Centers only for Health Screening $(\mathrm{N}=150)$} \\
\hline & & Details & Result & Details & Result \\
\hline \multirow{5}{*}{$\begin{array}{c}\text { Better- } \\
\text { than }\end{array}$} & 1 & female gynecologist & 0.83 & queue relocation & 0.82 \\
\hline & 2 & immediate description of result & 0.82 & female gynecologist & 0.82 \\
\hline & 3 & not too long waiting time & 0.81 & quick results notification & 0.82 \\
\hline & 4 & quick results notification & 0.81 & complaint response team/kindness of staff & 0.79 \\
\hline & 5 & queue relocation & 0.81 & individual equip. for examination status/meals served & 0.79 \\
\hline \multirow{5}{*}{$\begin{array}{c}\text { Worse } \\
\text {-than }\end{array}$} & 1 & cleanliness of gown/space & -0.92 & prevention of infection & -0.89 \\
\hline & 2 & prevention of infection & -0.90 & cleanliness of gown/space & -0.88 \\
\hline & 3 & emergency response to complications & -0.83 & kindness of staff & -0.80 \\
\hline & 4 & kindness of staff & -0.80 & rest after endoscopy & -0.80 \\
\hline & 5 & rest after endoscopy & -0.79 & emergency response to complications & -0.77 \\
\hline
\end{tabular}




\section{2. 연구의 한계 및 제언}

본 연구에서는 종합병원 내 건강검진센터와 종합건강검진 전문기관에 대해 특징적으로 서로 다른 결과에 대해서만 비교 하였으나, 두 집단 간의 차이에 대해 구체적으로 검증하지 못 하였다. 또한, 종합건강검진을 수행하는 종합병원과 전문기관 을 규모나 의료진 구성, 최신 의료장비 등에 따라 세분화하여 분석하지 못하였다. 향후 연구에서는 대상지역과 대상자를 확 대하고 세분화하여 종합건강검진 서비스 품질에 대한 더욱 다 양한 연구로 질병 예방과 조기 검진을 목적으로 하는 종합건 강검진 서비스 품질 개선과 의료서비스 시장의 확대에 기여하 길 기대해 본다.

\section{References}

Basfirinci, C., \& Mitra, A.(2015). A Cross Cultural Investigation of Airlines Service Quality through Integration of SERVQUAL and the Kano Model. Journal of Air Transport Management, 42(1), 239-248.

Brady, M. K., \& Cronin, J. J. Jr. (2001). Some new thoughts on conceptualizing perceived service quality: A hierarchical approach. Journal of marketing, 65(3), 34-49.

Choi, C. J., \& Cho, H. R. (2015). Mediating effect of trust in relationships between perceived quality of the medical service and hospital image and revisit intent. Korean journal of hospital management, 20(2), 57-71.

Chung, J. Y. (2016). An evaluation research on the quality components for the service design of health screening: Focusing on KANO model (Doctorial dissertation). Hongik University, Seoul, Korea.

Cronin, J. J. Jr., \& Taylor, S. A. (1992). Measuring service quality: A reexamination and extension. Journal of marketing, 56(3), 55-68.

Dominici, G., \& Palumbo, F.(2015). The Drivers of Customer Satisfaction for Academic Library Services Managerial Hints from an Empirical Study on Two Italian University Libraries using the Kano Model. International Journal of Management in Education, 9(3), 267-289.

Gruber, T., Abosag, I., Reppel, A., \& Szmigin, I.(2011). Analysing the Preferred Characteristics of Frontline Employees Dealing with Customer Complaints?: A Cross-National Kano Study. TQM Journal, 23(2), 128-144.

Im, B. H., \& Choi, H. S. (2014). Determination Factors and Satisfaction of Health Screening Center by Health Examination at Hospital. Journal of Digital Convergence, 12(12), 457-467.

Kang, S. W., You, C. H., \& Kwon, Y. D. (2009). The Determinants of the Use of Opportunistic Screening Programs in Korea. Journal of Preventive Medicine and Public Health, 42(3), 177-182.
Kano, N., Seraku, N., Takahashi, F., \& Tsuji, S. (1984). Attractive quality and must-be quality. Journal of The Japanese Society for Quality Control, 14(2), 147-156.

Kim, J. H., \& Park, C. M. (2015). Improvement Prioritization of Health and Medical Service Quality Attributes using PCSI Index-Focused on One Upper Level General Hospital. Korea Journal of Hospital Management, 20(2), 39-56.

Kim, S. C. (2010). A Study on the Service Quality Improvement by Kano Model \& Weighted Potential Customer Satisfaction Index. Journal of Distribution Science, 8(4), 19-25.

Kim, S. O., Youn, S. H., \& Lee, M. J. (2018). The Study on the e-Service Quality Factors in m-Shopping Mall App based on the Kano Model. International Journal of Industrial Distribution \& Business, 9(12), 63-72.

Kim, Y. M., Park, J. H., \& Kim, W. J. (2013). Analysis of Utilization Characteristics, Health Behaviors and Health Management Level of Participants in Private Health Examination in a General Hospital. Journal of the Korea Academia-Industrial cooperation Society, 14(1), 301-311.

Kim, Y. T., Lee, Y. H., \& So, K. S. (2019). The Effect of Convenience of the Comprehensive Screening Center on the Medical Service Value, Satisfaction and Brand Loyalty. Journal of the Korea Service Management Society, 20(1), 223-245.

Korea consumer Agency (2017, October 30). Survey on customer satisfaction of comprehensive screenings. Retrieved from http://www.kca.go.kr/brd/m_32

Lee, H. I. (2016). A study on the effects of medial care service quality factor of medical examination center on service value, customer satisfaction and behavioral intention: Based on the Kano model (Doctorial dissertation). Hongik University, Seoul, Korea.

Lee, J. H., \& Lee, H. J. (2014). The Effects of Medical Tourism Service Quality on Satisfaction and Behavioral Intentions of Russian Medical Tourists. International Journal of Tourism and Hospitality Research, 28(7), 103-116.

Lee, Y. C., Seo, D. H., \& Song, S. H. (2017). Classification and Evaluation of Service Quality Factor's of $\mathrm{O} 2 \mathrm{O}$ Delivery Applications Using Kano Model. Journal of Industrial Convergence, 15(2), 27-36.

Maciosek, M. V., Coffield, A. B., Edwards, N. M., Flottemesch, T. J., Goodman, M. J., \& Solberg, L. I. (2006). Priorities among effective clinical preventive services: Results of a systematic review and analysis. American journal of preventive medicine, 31(1), 52-61.

Milutinović, D., Milovanović, V., Pjević, M., MartinovCvejin, M., \& Cigić, T. (2009). Assessment of quality of care in acute postoperative pain management. Vojnosanitetski pregled, 66(2), 156-162.

Parasuraman, A., Zeithaml, V. A., \& Berry, L. L. (1985). A conceptual model of service quality and its 
implications for future research. Journal of marketing, 49(4), 41-50.

Park, H. Y., \& Park, S. Y. (2017). The Influence of Service Quality Factors on Reuse Intention. Journal of Distribution Science, 15(4), 59-67.

Park, Y. S., Kim, Y. M., \& Kang, S. H. (2015). A Study on the Determinants of Rescreening for Using the Private Health Screening Program. Journal of Digital Convergence, 13(1), 383-396.

Rahmana, A., Kamil, M., Soemantri, E., \& Olim, A. (2014). Integration of SERVQUAL and Kano Model into QFD to Improve Quality of Simulation-Based Training on Project Management. International asic and Applied Science, 2(3), 59-72.

Salehzadeh, R., Shahin, A., \& Kazemi, A. (2015). Is Organizational Citizenship Behavior an Attractive Behavior for Managers?: A Kano Model Approach. Journal of Management Development, 34(5), 601-620.

Shahin. A. (2016). Estimating Customer Lifetime Aalue for New Product Development Based on the Kano Model with a Case Study in Automobile Industry. Benchmarking: An International Journal, 22(5), 857-873.

Shelton, P. J. (2000). Measuring and improving patient satisfaction. Burlington, MA: Jones \& Bartlett Learning.
Shin, Y. S., Park, C. Y., Jung, S. H., Jung H. Y., \& Kang, H. Y. (2006). Comparison of customer satisfaction with health examination programs provided by the Korea National Health Insurance and private healthcare organizations in Korea. Journal of Korean Society of Quality Assurance in Health Care, 12(1), 40-51.

Taifa, I. W., \& Desai, D. A. (2015). Quality Function Deployment Integration with Kano Model for Ergonomic Product Improvement-A Review. Journal of Multidisciplinary Engineering Science and Technology, 2(9), 2284-2491.

Timko, M. (1993). An experiment in continuous analysis. Center for Quality of Management Journal, 2(4), 17-20.

Walden, D. (1993). Introduction to Kano's methods. Center for Quality of Management Journal, 2(4), 3-7.

Yang, H. J., Kim, J. S., Lee, J. K., \& Lee, J. S. (2006). Evaluation of Scientific Evidence for Health Screening Tests Provided by Some Hospitals in Korea. Korean Journal of Family Medicine, 27(9), 723-732.

Yeo, J. Y., \& Jeong, H. S. (2012). Determinants of health screening and its effects on health behaviors. Health Policy and Management, 22(1), 49-64. 